heart was markedly dilated with a hypertrophic right ventricle. The tricuspid valve had only two leaflets. The foramen ovale was probe patent and the ductus arteriosus was open. Additionally, there was a Meckel's diverticulum and markedly hyperlobulated kidneys. The external genitalia were normal in appearance but the vagina showed a marked cobblestone mucosa.

\section{Cytogenetic Studies}

Cytogenetic studies from case 1 included cultures of peripheral blood and skin fibroblasts. Karyotypes from both cultures showed trisomy $\mathrm{D}(47, \mathrm{XX},+\mathrm{D})$. Giemsa banding of cells from the skin fibroblast culture, using a modification of the method of Seabright (1971), showed 47,XX, +13 (Fig. 3). Chromosome analysis of peripheral leucocytes of the parents were normal.

In case 2 the karyotype from a peripheral blood culture demonstrated 46,XX, $-\mathrm{D},+\mathrm{t}(\mathrm{DqDq})$. Giemsa banding showed that the translocation involved chromosomes Nos. 13 and 14, and the missing D chromosome was No. 14 (Fig. 4). The karyotype from the affected child could then be specified as $46, \mathrm{XX},-14,+\mathrm{t}(13 \mathrm{q} 14 \mathrm{q})$, and was therefore consistent with trisomy 13 syndrome. The parents were not available for chromosome study.

\section{Discussion}

Including the present study, an extra D chromosome or unbalanced DqDq translocation has been reported in eight of 17 cytogenetic studies of infants with cyclopia. All of these eight infants had extracephalic malformations of trisomy 13 phenotype in addition to cyclopia. Trisomy 13 has been verified by autoradiography in one patient (Arakaki and Waxman, 1969) and by Giemsa banding in the two patients reported here. In one of our patients the trisomy 13 resulted from an unbalanced 13q14q translocation. These observations confirm that the faciocerebral malformations of trisomy 13 syndrome may be expressed in the extreme as cyclopia.

The authors wish to thank Mrs Fay Kaplan and Mr Paul Brager for technical assistance and Drs A. L. Wittman, M. Rose, and R. Silton who performed the necropsy examinations. The photographs were taken by Mr David Larkin.

Atsuko Fujimoto, Allan J. EbBin, Joseph W. TOWNER, and Miriam G. WILSON

Genetics Division, Department of Pediatrics, University of Southern California School of Medicine, Los Angeles, California 90033, USA

\section{REFERENCES}

Arakaki, D. T. and Waxman, S. H. (1969). Trisomy D in a cyclops. fournal of Pediatrics, 74, 620-622.

Batts, J. A., Jr., Punnett, H. H., Valdes-Dupena, M., Coles, J. W., and Green, W. R. (1972). A case of cyclopia. American fournal of Obstetrics and Gynecology, 112, 657-661.

Cohen, M. M. (1966). Chromosomal mosaicism associated with a case of cyclopia. Fournal of Pediatrics, 69, 793-798.

Cohen, M. M., Storm, D. F., and Capraro, V. J. (1972). A ring chromosome (No. 18) in a cyclops. Clinical Genetics, 3, 249-259. DeMyer, W. (1964). A 46 chromosome cebocephaly with remarks on the relation of 13-15 trisomy to holoprosencephaly (arhinencephaly). Annales Paediatrici, 203, 169-177.

Faint, S. and Lewis, F. J. W. (1964). Personal communication.

Golob, E. Schaller, A., and Kunze-Mühl, E. (1972). Zyclopie. mit D-trisomie. Wiener klinische Wochenschrift, 84, 272-275.

Halbrecht, I., Kletzky, O., Komlos, L., Lotker, M., and Gersht, N. (1971). Trisomy-D in cyclops. Obstetrics and Gynecology, 37, 391-393.

Harnden, D. G., Jacobs, P. A., and Buckton, K. E. (1961). Personal communication. In Sohval, A. R. Recent progress in human chromosome analysis and its relation to the sex chromatin. American fournal of Medicine, 31, 397-441.

Juberg, R. C. (1966). Personal communication. In Cohen, M. M. Chromosomal mosaicism associated with a case of cyclopia. Fournal of Pediatrics, 69, 793-798.

Lejeune, J. (1966). Personal communication. In Cohen, M. M. Chromosomal mosaicism associated with a case of cyclopia. fournal of Pediatrics, 69, 793-798.

Lieber, E., Hsu, L. Y, F., Gertner, M., Strauss, L., and Hirschhorn, K. (1970). Cytogenetic studies in holoprosencephaly. (Abstr.) Program and Abstracts, p. 126. The American Pediatrics Society and the Society for Pediatric Research.

Nitowsky, H. M., Sindhvananda, N., Konigsberg, U. R., and Weinberg, T. (1966). Partial 18 monosomy in the cyclops malformation. Pediatrics, 37, 260-269.

Pfitzer, P. (1967). Extra minute chromosome in cyclops. Lancet, 2, 102-103.

Seabright, M. (1971). A rapid banding technique for human chromosomes. Lancet, 2, 971-972.

Taysi, K. and Tinaztepe, K. (1972). Trisomy D and the cyclops malformation. American fournal of Diseases of Children, 124, 710 713.

Toews, H. A. and Jones, H. W. (1968). Cyclopia in association with $\mathrm{D}$ trisomy and gonadal agenesis. American fournal of Obstetrics and Gynecology, 102, 53-56.

\section{A New Case of Trisomy for the Short Arm of No. 9 Chromosome}

Summary. A new case with trisomy for the short arm of No. 9 chromosome, identified by heat treatment and Giemsa staining is reported. The clinical picture and dermatoglyphic patterns are similar to those previously reported.

Received 10 April 1973. 

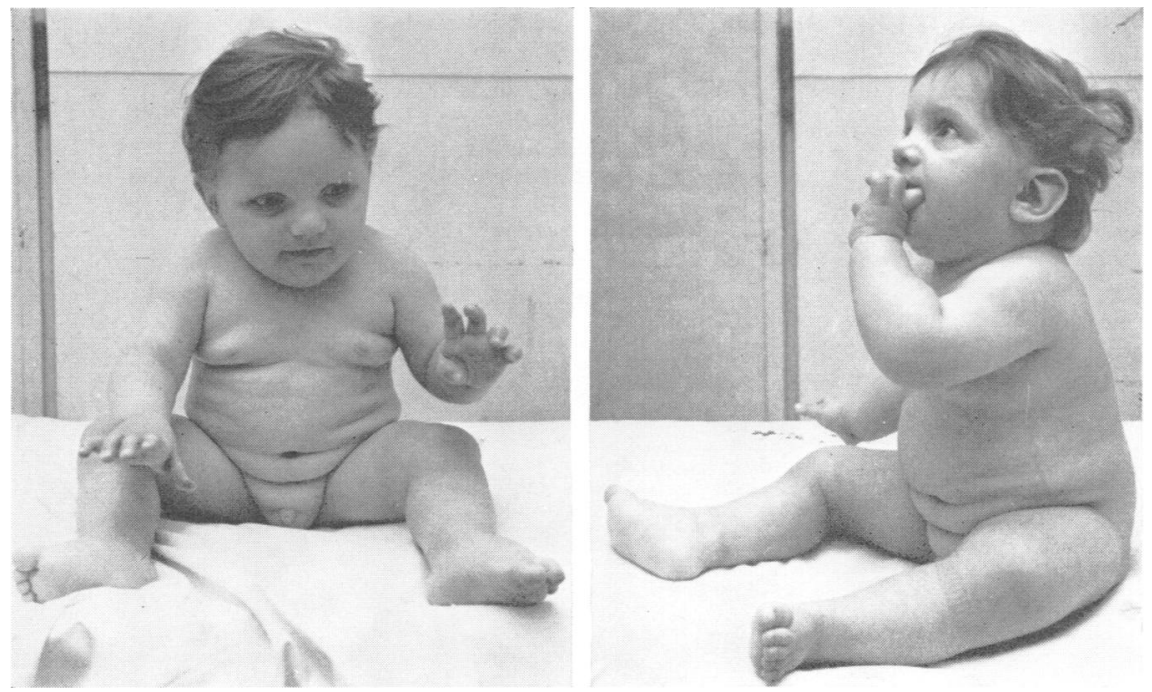

Fig. 1. Front and side view of the patient; note the malformed nose and ears.

Rethoré and his coworkers (1970) described a new clinical pattern characterized by microbrachicephaly, oblique antimongoloid palpebral fissures, hypertelorism, malformed ears, phalangeal hypoplasia, dermatoglyphic anomalies, and mental retardation. The karyotype showed a trisomy for the short arm of the No. 9 chromosome.

We briefly report a new case, not related to the case previously described.

\section{Case Report}

The child (Fig. 1), 4 months old, is the second of two sibs born to nonconsanguineous parents. The father and mother were aged 29 and 26 years, respectively at his birth. The parents and brothers were phenotypically normal and healthy. The mother had been taking an oral contraceptive daily for three months before the time of conception because of polymenorrhoea and dysmenorrhoea.

Birth weight was $2850 \mathrm{~g}$. The neonatal period was uneventful. The growth was normal and at 4 months the weight was $5800 \mathrm{~g}$ and the length $60 \mathrm{~cm}$. There was a wide anterior fontanelle $(30 \times 30 \mathrm{~cm})$. The ears were large and low set with a small antihelix. The eyes showed convergent strabismus on the right side, palpebral fissures slanting downwards and laterally and hypertelorism $(20 \mathrm{~mm}$ between the carunculae-lacrimalis). The bridge of the nose was flat and the palate was high and arched. The neck was broad and short. There were dysplastic middle phalanges of the second and fifth fingers on the right hand and of the second, third, fourth, and fifth fingers of the left hand with bilaterally curved fifth fingers.
Routine tests on blood and urine were normal on several occasions and a urinary amino-acid chromatogram was normal.

Radiological examination showed a normal bone structure except for slow maturation; an intravenous pyelogram showed no anomalies. EEG and ECG were normal and QD was 77.

At 13 months he weighed $10,700 \mathrm{~g}$; however a certain degree of mental retardation was noted and QD was 75 .

\section{Dermatoglyphic Studies (M. O. Rethoré)}

Right Palm. Simian crease; palmar triradius on $t^{\prime}$ terminates at 13 ; digital triradius-a terminates at $4, \mathrm{~b}$ at $7, \mathrm{~d}$ at 11 , and $\mathrm{c}$ is absent. There is an absence of thenar and hypothenar patterns. Fingertips show an ulnar loop on the first and the third finger, an arch on the second and fifth, and a whorl on the fourth.

Left Palm. Simian crease; palmar triradius on $t^{\prime}$ terminates at 13; digital triradius-a terminates at $4, b$ at $5, d$ at 9 , and $c$ is absent. There is a whorl on the thenar area. Fingertips show an ulnar loop on the third finger, an arch on the first, second, and third fingers, and a whorl on the fourth finger.

\section{Cytogenetic Studies}

In the chromosomal analysis from peripheral blood culture all cells were found to have an abnormal C-sized chromosome replacing a member of the 


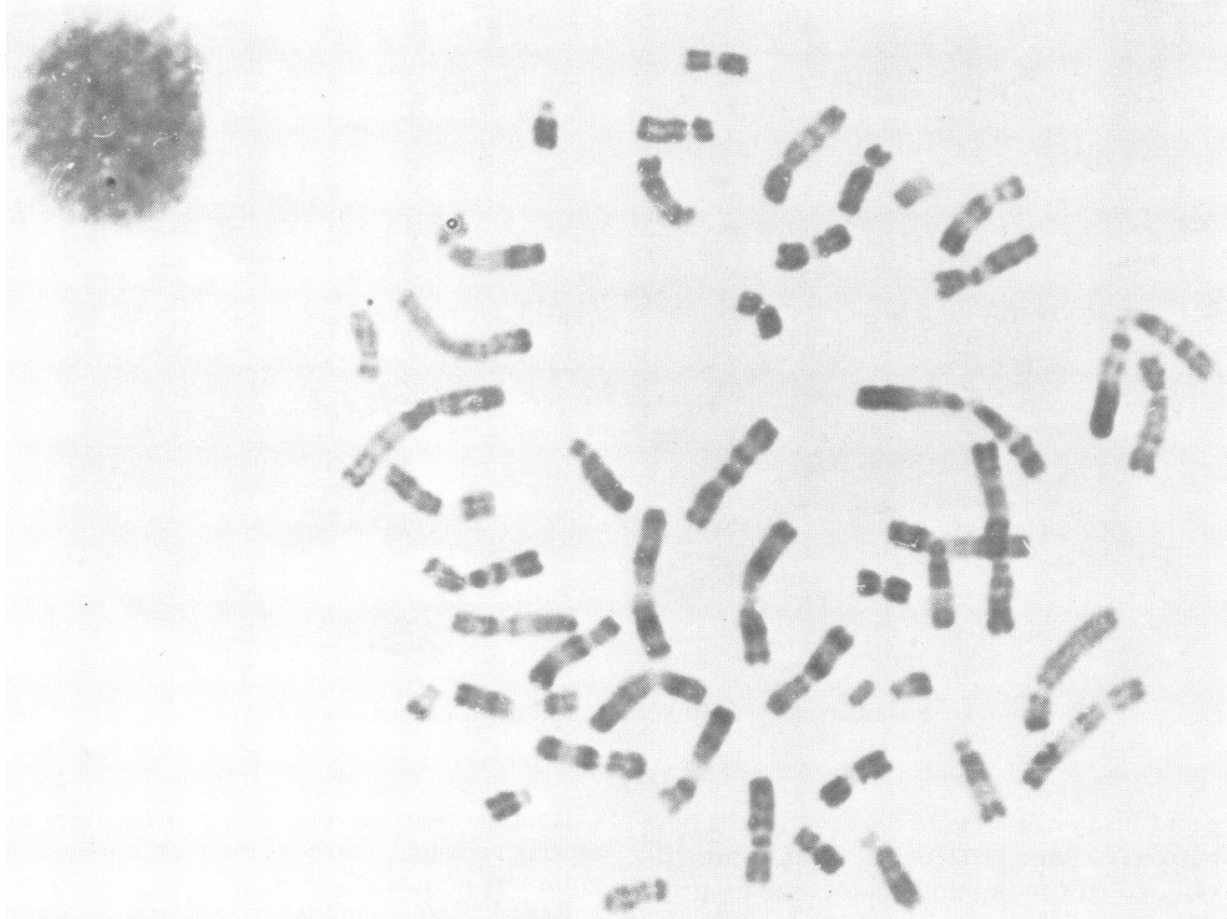

FIG. 2a

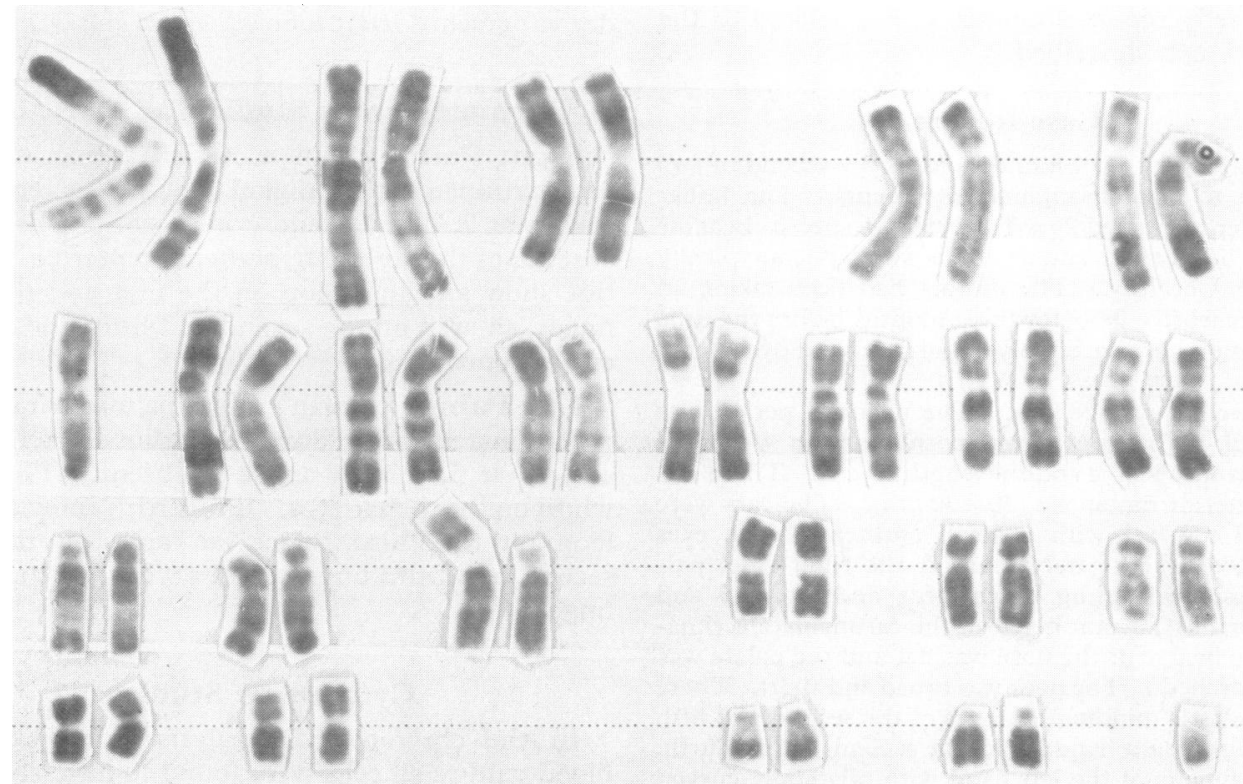

FIG. 2b

Figs. 2a and b. Karyotype of the patient showing the abnormal No. 15 chromosome (R-type banding pattern). 
D group. On the long arm of this abnormal chromosome a secondary constriction was demonstrated. Heat treatment and Giemsa staining (Dutrillaux and Lejeune, 1971) revealed that this chromosome was formed from a No. 15 chromosome and by the short arm of a No. 9 chromosome; the other chromosomes were normal (Figs. 2a and b). Therefore there was a trisomy for the short arm of the No. 9 chromosome. The chromosome pattern after heat treatment and Giemsa staining was normal in the parents and the brother.

\section{Discussion}

As far as we know only 10 cases of this trisomy have been described (Rethoré et al, 1970; Cantu, Buentello, and Armendares, 1971; Hoehn, Engel, and Reinwein, 1971; Rott, Schwanitz, and Grosse, 1971) and a complete review is given by Rethoré $e t$ al (1973).

The malformations and the dermatoglyphics of our case are quite similar to those previously described but the mental retardation is not so severe.

In our case the trisomy for the short arm of the No. 9 chromosome can be considered 'pure', since deletion of the short arm of the No. 15 chromosome is not usually associated with phenotypic anomalies.

However it is noticeable that in Rethoré's series one case (case 10) had the same cytogenetic findings but with very severe mental retardation $(\mathrm{QD}=45)$.

We are grateful to Professor J. Lejeune and Dr M. O. Rethore for confirming the chromosomal anomaly, for the dermatoglyphic studies, and for the manuscript revision.

Carlo Baccichetti and Romano Tenconi Pediatric Clinic, University of Padua, Italy

\section{REFERENCES}

Cantu, J. M., Buentello, L., and Armendares, S. (1971). Trisomie $\mathrm{Cp}$ : un nouveau syndrome. Annales de Génétique, 14, 177-186.

Dutrillaux, B. and Lejeune, J. (1971). Sur une nouvelle technique d'analyse du caryotype humain. Comptes Rendus Hebdomadaires des Séances de l'Académie de Sciences, 272, 2638-2640.

Hoehn, H., Engel, W., and Reinwein, H. (1971). Presumed trisomy for the short arm of No. 9 chromosome not due to inherited translocation. Humangenetik, 12, 175-181.

Rethoré, M. O., Larget-Piet, L., Abonyi, D., Boeswillwald, M., Berger, R., Carpentier, S., Cruveiller, J., Dutrillaux, B., Lafourcade, J., Penneau, M., and Lejeune, J. (1970). Sur quatre cas de trisomie pour le bras court du chromosome 9 . Individualisation d'une nouvelle entité morbide. Annales de Génétique, 13, 217-232.

Rethoré, M. O., Hoehn, H., Rott, H. D., Couturier, J., Dutrillaux, B., and Lejeune, J. (1973). Analyse de la trisomie 9p par dénaturation ménagée. A propos d'un nouveau cas. Humangenetik. (In press.)

Rott, H. D., Schwanitz, G., and Grosse, K. P. (1971). Partielle Trisomie Cq bei balancierter B4/C 9 Translokation bei der Mutter. Zeitschrift für Kinderheilkunde, 109, 293-299.

\section{Developmental Abnormalities Associated with a Ring Chromosome $6^{*}$}

\begin{abstract}
Summary. A clinical and cytogenetic report is made of a patient with microcephaly, peculiar facies, and retardation of physical and mental development, who possesses a karyotype containing a ring chromosome No. 6 identified by Q-staining with quinacrine mustard. This is the first report of a ring autosome in the $\mathrm{C}$ group to be identified. Comparison with other patients reported as having C-group autosomal rings failed to reveal many common phenotypic characteristics.
\end{abstract}

While ring chromosomes are rare, they have been observed in each of the seven chromosomal groups, including at least 10 cases in the $\mathrm{C}$ group (Turner $e t$ $a l, 1962$; Smith-White et al, 1963; Atkins et al, 1966/67; Butler, France, and Jacoby, 1967; Bueno, del Amo, and Hermida, 1969; Wurster et al, 1969; Gacs, Schuler, and Sellyei, 1970; Kistenmacher and Punnett, 1970; Therkelsen, Møller, and Henningsen, 1971; de Chieri et al, 1972). None of the Cgroup chromosomes involved in the ring formation was identified. We report here another C-group ring chromosome shown to involve a No. 6 chromosome.

\section{Case Report}

The proposita (SH 512 463) was the product of an uncomplicated pregnancy, labour, and delivery. At birth the patient weighed $2910 \mathrm{~g}$, measured $48.2 \mathrm{~cm}$ in length, and had a head circumference of $32 \cdot 2 \mathrm{~cm}$. The patient's mother and father were 26 and 27 years of age, respectively, at the patient's birth. Two older sibs, a brother and sister, are described as being in excellent health. There are no known instances of birth defects, mental retardation, or recurring abortion on either side of the family.

The patient's developmental milestones have been delayed with spontaneous sitting, standing, and walking occurring at 11,22 , and 26 months, respectively. Intelligible speech was still lacking at 24 months of age. Throughout the first $2 \frac{1}{2}$ years of development, the patient's length, weight, and head circumference have consistently been below the third centile.

\footnotetext{
Received 23 February 1973.

* Reprint requests to: Dr Charleen M. Moore, Program in Pediatrics, University of Texas Medical School at Houston, Freeman Building, Texas Medical Center, Houston, Texas 77025, USA.
} 